\title{
The Linguistic Expressions of Danshu (Provisos) in Chinese Laws
}

\author{
Daohua Hu', Changgang Jiang² \\ ${ }^{1}$ School of Languages and Cultures, Shanghai University of Political Science and Law, Shanghai, China \\ ${ }^{2}$ School of Foreign Languages, Qingdao Agricultural University, Qingdao, China \\ Email: hudaohua01@126.com
}

How to cite this paper: $\mathrm{Hu}, \mathrm{D}$. H., \& Jiang, C. G. (2021). The Linguistic Expressions of Danshu (Provisos) in Chinese Laws. Open Journal of Modern Linguistics, 11, 395-414. https://doi.org/10.4236/ojml.2021.113030

Received: May 17, 2021

Accepted: June 20, 2021

Published: June 23, 2021

Copyright (c) 2021 by author(s) and Scientific Research Publishing Inc. This work is licensed under the Creative Commons Attribution International License (CC BY 4.0).

http://creativecommons.org/licenses/by/4.0/

\begin{abstract}
In legislative texts, proviso is used to provide for exceptions or to add certain conditions to the provisions in the main clause. In Chinese legislative texts, proviso is called danshu, for it is initiated by the words dan/danshi. The linguistic expressions of danshu have not been fully described. This study, based on a self-built mini-corpus of danshu of Chinese legislative texts, aims to describe the linguistic expressions of danshu, summarize the syntactic patterns and core words thereof, and explain the reasons. This study will shed light on the normalization of Chinese legislative texts, especially the linguistic expressions of danshu, improve the quality of Chinese legislation, and enrich the study of provisos in legislative texts other than those in English language.
\end{abstract}

\section{Keywords}

Linguistic Expressions, Danshu (Provisos), Chinese Laws, Syntactic Pattern, Lexis, Civil Code

\section{Introduction}

Variability is inherent in human language: people use different linguistic forms on different occasions, and different speakers of a language will say the same thing in different ways. Most of this linguistic variation is highly systematic (Biber \& Conrad, 2009: p. 4). For example, the subfield of English for Specific Purposes (ESP) focuses on description of the language used in registers and genres from a particular profession or academic discipline, with its goal of developing instructional materials that will help students learn the particular language patterns that are typical for the different situations and different kinds of texts in those fields (Biber \& Conrad, 2009: p. 3).

${ }^{1}$ The words "the People's Republic of China" is omitted in the names of Chinese laws in this study. 
Similarly, the language of law is the product of long-term integration of legislative activities and language, which is different from the languages of other fields (Mellinkoff, 2014; Zhou, 2009: p. 478). The style of the language of law is stable (Liu, 2018: p. 7), and due to its unique pragmatic function, the meaning and use of many language units in it have changed, showing a deviation from the daily language use (Yu \& Wang, 2017). The syntactic patterns, types and structures of the language of law are subject to the logical structure and meaning of "legislative sentence", so only by combining the above aspects can we break through the research dilemma of legislative sentences so far (Pan, 2017: p. 188). Therefore, from the logical structure of legal norms, the logical structure of legislative sentences and syntactic patterns, and the classification of danshu, this study has described the syntactic patterns and the rules of various danshu in Chinese laws, so as to provide a reference for the standardization of linguistic expressions thereof.

According to the white paper on The Socialist System of Laws with Chinese Characteristics in 2011, the socialist legal system with Chinese characteristics has been established, and China's legislation should prefer quality to speed and quantity since then. In terms of its legislation scale, China can be called a legislative power, but current research of the language of law is not commensurate with this status. In fact, in the local and central laws and regulations, and even in some important national laws or regulations, language problems in words, sentences, punctuation are not uncommon. This is directly related to our inadequate use of language, especially the language of law, and the relatively rough research on it (Pan, 2017: p. 181).

\section{Literature Review}

\subsection{The Definition and Linguistic Marker of danshu (Proviso)}

The term proviso refers to a provision that begins with words provided that and supplies a condition, exception, or addition in drafting (Garner, 2019: p. 1481). In English legal documents, proviso is often emphasized in capitals and may come in the form PROVIDED THAT; or PROVIDED ALWAYS THAT; or PROVIDED FURTHER THAT; or PROVIDED NEVERTHELESS THAT (Doonan \& Foster, 2001: p. 159). In Chinese laws, a proviso begins with the words dan (but) or danshi (but/however), so it is called danshu in Chinese (Editorial Board, 2010: p. 0324).

\subsection{The Logical Structure and Syntactic Structure of Legislative Provisions}

In 1843, George Coode wrote a memorandum On Legislative Expression in which he came to the conclusion that legal sentences in statutes consisted of four parts, namely the case, the condition, the legal subject, and the legal action (Crystal \& Davy, 1969: p. 217). There is no one-to-one correspondence between the four parts of legal sentences and syntactic elements. In fact, it is a logical analysis of 
legislative sentences, but it provides a logical or semantic framework for legislative sentences. Therefore, the general structure of English legislative sentence is "If $x$, then Y shall be (or do) Z" (Tammelo, 2012: p. 86).

Based on the analysis of Chinese legislative provisions, Pan Qingyun (2004; 2017: pp. 189-190) proposed two logical structures of legislative sentences: 1) condition + legal subject + legal action; 2) condition + subject + action + sanction. The first logical structure is applicable to the legislative sentences of compulsory and authorization legal norms. The condition in logical structure corresponds to the assumption of legal norms. The second logical structure is the standard format of prohibitory normative legislative sentences. Comparing the two structural patterns, it can be found that both consist of condition, legal subject and legal action, and sanctions only in the second logical structure. Therefore, this study integrates the two logical structure models of Professor Pan into one structural model, and takes sanctions as the option, that is, the logical structure of legislative sentences is condition + subject + action + (sanction).

\subsection{The Classification of danshu}

Legal norms, according to their content, can be divided into three types, namely authorization norms, obligatory norms and compound norms (Zhang, 2018: pp. 117-118). Authorization norms grant the freedom to people who can act or not or require others to act or not, and they are usually expressed with the words "may", "be entitled to", "enjoy the freedom" etc. The freedom of conduct stipulated by the authorization norms can be divided into two subclasses, namely negative freedom and positive freedom (Zhu \& Ye, 2015: p. 248). Obligatory norms, including negative obligation and positive obligation, directly require people to act or not to act. Positive obligation are often expressed with the words "shall", "must" etc., while negative obligation with the words "shall not", "prohibit" etc., or add adverse legal consequences to the description of behaviors. The compound norms refer to those that grant freedom and require obligations simultaneously, and most of which are about the organization and activities of state organs.

In terms of content, danshu include three types of legal norms, which are used to guide the conduct of legal subject (Sun, 2006: p. 136), similarly, danshu can also be divided into "authorization danshu", "obligatory danshu" and "compound danshu".

As for the function, Black's Law Dictionary (11th Edition) points out that a proviso is to propose condition, exception or addition (Garner, 2019: p. 1481). Zhou Wangsheng (1998: pp. 487-490) summarizes five functions of danshu: First, to seek the common ground while reserve difference; second, to seek the degree by applying restriction; third, to seek perfection in the way of saving deviation; fourth, to seek comprehensiveness and appropriateness by addition; and fifth, to make the special provisions conspicuous, clear, emphasized and distin- 
guished from the general provisions. Sun Yihua (2006: p. 136) argues that a danshu is to put forward exceptions, additional conditions or restrictions to the general provisions of the main clause. This study, based on their content, classifies danshu in Chinese legislative texts into four types: authorization danshu, obligatory danshu, compound danshu, and exclusive danshu. ${ }^{3}$

\subsection{The Linguistic Expressions of danshu}

The pragmatic environment of danshu is "main clause plus danshu". Zhou Wangsheng (1991: pp. 57-58) divides danshu into six types: 1) to express exclusion, with such sentence pattern as dan/danshi ... chuwai (but ... except); 2) to express authorization, such as dan/danshi ... keyi (but ... may); 3) to express requirements, such as dan/danshi ... yingdang (but ... shall); 4) to express commands, such as dan/danshi ... bixu (but ... must); 5) to express prohibition, such as dan/danshi ... bude (but ... shall not); 6) to express negation, such as dan/danshi ... bu renwei (but ... not consider). Luo Huiting and Wang Shan (2018) makes statistics on the expressions of danshu and finds that there are 19 forms of danshu initiated by the word dan, and 27 forms by danshi. But the study does not classify and systematize the various forms of danshu. Zhou Wangsheng's six types of danshu mix the types of legal norms (i.e., authorization, requirement and prohibition), function of danshu (i.e., exclusion) and sentence types (i.e., imperative and negation), which are somewhat confusing. What's more, Zhou's study gives a few instances of danshu. Luo Huiting and Wang Shan (2018) adopt quantitative research method, but it does not connect the expressions of danshu with the classification of legal norms. This study aims to investigate the linguistic expressions of danshu based on their specific types.

\section{Research Methods}

\subsection{The Analytical Framework of danshu}

According to Black's Law Dictionary (11th Edition), Zhou Wangsheng (1991; 1998: pp. 486-487), and Zhang Wenxian (2018: pp. 117-118) ${ }^{3}$, the danshu in Chinese laws can be classified into four types: authorization danshu, obligatory danshu, compound danshu, and exclusive danshu. The exclusionary danshu include three subclasses, namely exclusion of the situations, the objects ${ }^{4}$ and the subjects ${ }^{5}$ respectively; the authorization danshu include two subclasses of positive freedom and negative freedom; the obligatory danshu include two subclasses of positive obligations and negative obligations, and the compound danshu will

\footnotetext{
${ }^{3}$ Authorization norms, compulsory norms and compound norms are classified from the content of legal norms. As a special legal norm, danshu (proviso) shares the same characteristics of legal norms. In addition, one of its important functions is to exclude the application of certain legal rules to certain situations, subjects or objects. In this study, the exclusionary danshu is regarded as a subclass.

${ }^{4}$ The objects refer to the intermediary between the obligee and obligor, and the objects of the rights and obligations thereof (Zhang, 2018: p. 157).

${ }^{5}$ The subjects refer to the person who enjoys rights and performs obligations in legal relationship, including natural person, legal person, state, state organ and other subjects (Zhang, 2018: pp. 155-156).
} 
not be further classified. The classification and use frequency of danshu are as follows in Table 1 below.

\subsection{Research Questions}

1) What is the overall use of danshu in Chinese legislative texts?

2) What are the linguistic expressions of various types of danshu?

3) What is the development trend of the linguistic expressions of danshu?

\subsection{A mini-Corpus of danshu}

This study collects 100 laws formulated by National People's Congress of the People's Republic China and its Standing Committee, involving eight legal departments, totaling 848,693 Chinese characters. Among them, 38 laws don't have sentences with the words danshildan and are excluded. The remaining 62 laws have 7087 articles in total, and 587 sentences with the words dan/danshi, in which 438 sentences initiated by danshi and 149 by dan respectively. The 587 sentences initiated by the words danshildan are extracted and annotated manually one by one, among which 45 non-danshu sentences are eliminated, and finally 542 instances are collected to create a mini-corpus of legal danshu. The name of the laws, number of articles, danshu, and non-danshu are shown in Table 2 below.

\section{Results and Discussion}

\subsection{The Number of danshu in Chinese Laws Is Relatively Small}

There are 7087 articles in the 62 laws, but only 587 sentences with the words danshildan. Among which only 542 instances of danshu, 45 non-danshu instances are excluded. It is obvious that the number of danshu is relatively small (see Table 2). Zhou Wangsheng (1998: pp. 493-494) finds that there is a low frequency of danshu in China's laws, regulations, rules and other normative documents, and many laws, regulations and rules have no danshu at all.

From Zhou Wangsheng's point of view, there are two basic reasons: first, the danshu of the laws are not comprehensive and meticulous. Second, the legislative

Table 1. The analytical framework of danshu.

\begin{tabular}{cc}
\hline Classification of danshu & Subclasses of danshu \\
\hline Exclusionary danshu & Exclusion of the situations \\
& Exclusion of the objects \\
Obligatory danshu & Exclusion of the subjects \\
\hline Authorization danshu & Positive obligations \\
& Negative obligations \\
\hline Compound danshu & Positive freedom \\
\end{tabular}


Table 2. The laws, number of articles, danshu and non-danshu.

\begin{tabular}{|c|c|c|c|c|c|c|}
\hline No. & Name of laws & No. of articles & $\begin{array}{l}\text { No. of sentences } \\
\text { with danshi }\end{array}$ & $\begin{array}{l}\text { No. of sentences } \\
\text { with dan }\end{array}$ & No. of danshu & $\begin{array}{c}\text { No. of } \\
\text { non-danshu }\end{array}$ \\
\hline 1 & Constitution & 143 & 5 & 3 & 6 & 2 \\
\hline 2 & Legislation Law & 105 & 5 & 0 & 4 & 1 \\
\hline 3 & Organic Law of Villagers' Committee & 41 & 3 & 1 & 4 & 0 \\
\hline 4 & Organic Law of Urban Residents' Committee & 23 & 3 & 0 & 3 & 0 \\
\hline 5 & Procedural Law of Treaty Conclusion & 21 & 3 & 0 & 3 & 0 \\
\hline 6 & Supervision Law & 69 & 0 & 2 & 1 & 1 \\
\hline 7 & Anti Terrorism Law & 97 & 0 & 1 & 1 & 0 \\
\hline 8 & Civil Code & 1260 & 223 & 0 & 218 & 5 \\
\hline 9 & Company Law & 218 & 18 & 9 & 25 & 2 \\
\hline 10 & Securities Law & 226 & 7 & 12 & 18 & 1 \\
\hline 11 & E-Commerce Law & 89 & 3 & 1 & 4 & 0 \\
\hline 12 & Electronic Signature Law & 36 & 2 & 0 & 1 & 1 \\
\hline 13 & Administrative License Law & 83 & 9 & 0 & 9 & 0 \\
\hline 14 & Administrative Review Law & 43 & 7 & 0 & 7 & 0 \\
\hline 15 & Law on Administrative Punishment of Public Servants & 68 & 6 & 0 & 6 & 0 \\
\hline 16 & Law on the Protection of Cultural Relics & 80 & 6 & 0 & 6 & 0 \\
\hline 17 & Lawyers Law & 60 & 3 & 2 & 5 & 0 \\
\hline 18 & Urban Real Estate Management Law & 73 & 2 & 3 & 4 & 1 \\
\hline 19 & Notarization Law & 47 & 1 & 3 & 4 & 0 \\
\hline 20 & Customs Law & 102 & 3 & 1 & 3 & 1 \\
\hline 21 & Land Management Law & 87 & 2 & 1 & 3 & 0 \\
\hline 22 & Rural Land Contract Law & 70 & 1 & 3 & 3 & 1 \\
\hline 23 & Civil Servant Law & 113 & 3 & 0 & 2 & 1 \\
\hline 24 & Administrative Penalty Law & 64 & 0 & 2 & 2 & 0 \\
\hline 25 & Nuclear Safety Law & 94 & 1 & 1 & 2 & 0 \\
\hline 26 & Higher Education Law & 69 & 1 & 1 & 2 & 0 \\
\hline 27 & Maternal and Infant Health Care Law & 39 & 0 & 2 & 2 & 0 \\
\hline 28 & Judge Law & 69 & 2 & 0 & 2 & 0 \\
\hline 29 & Mental Health Law & 85 & 2 & 0 & 2 & 0 \\
\hline 30 & People’s Jury Law & 32 & 0 & 2 & 2 & 0 \\
\hline 31 & Procurator Law & 70 & 2 & 0 & 2 & 0 \\
\hline 32 & Urban and Rural Planning Law & 70 & 1 & 0 & 1 & 0 \\
\hline 33 & Civil Aviation Law & 214 & 35 & 0 & 34 & 1 \\
\hline 34 & Food Safety Law & 154 & 8 & 3 & 9 & 2 \\
\hline 35 & Enterprise Income Tax Law & 60 & 0 & 9 & 3 & 6 \\
\hline 36 & Drug Administration Law & 155 & 4 & 1 & 4 & 1 \\
\hline
\end{tabular}




\section{Continued}

\begin{tabular}{|c|c|c|c|c|c|c|}
\hline 37 & Tourism Law & 112 & 3 & 1 & 4 & 0 \\
\hline 38 & Product Quality Law & 74 & 3 & 0 & 2 & 1 \\
\hline 39 & Highway Law & 87 & 2 & 1 & 3 & 0 \\
\hline 40 & Construction Law & 85 & 3 & 0 & 3 & 0 \\
\hline 41 & Ship Tonnage Tax Law & 22 & 0 & 4 & 2 & 2 \\
\hline 42 & Port Law & 62 & 2 & 0 & 2 & 0 \\
\hline 43 & Individual Income Tax Law & 22 & 0 & 1 & 1 & 0 \\
\hline 44 & Budget Law & 101 & 1 & 0 & 1 & 0 \\
\hline 45 & Trademark Law & 73 & 0 & 1 & 1 & 0 \\
\hline 46 & Labour Law & 107 & 2 & 0 & 2 & 0 \\
\hline 47 & Law on Protection of Women's Rights and Interests & 61 & 1 & 0 & 1 & 0 \\
\hline 48 & $\begin{array}{l}\text { Law on the Protection of the Rights and Interests of } \\
\text { the Elderly }\end{array}$ & 85 & 0 & 1 & 1 & 0 \\
\hline 49 & Occupational Disease Prevention and Control Law & 88 & 0 & 1 & 1 & 0 \\
\hline 50 & Land Occupation Tax Law & 16 & 0 & 4 & 2 & 2 \\
\hline 51 & $\begin{array}{l}\text { Law on Prevention and Control of Environmental } \\
\text { Pollution by Solid Waste }\end{array}$ & 126 & 4 & 1 & 4 & 1 \\
\hline 52 & Forest Law & 84 & 3 & 2 & 4 & 1 \\
\hline 53 & Wildlife Protection Law & 58 & 0 & 5 & 5 & 0 \\
\hline 54 & Marine Environmental Protection Law & 97 & 1 & 2 & 2 & 1 \\
\hline 55 & $\begin{array}{l}\text { Law on Prevention and Control of Environmental } \\
\text { Noise Pollution }\end{array}$ & 64 & 0 & 1 & 1 & 0 \\
\hline 56 & Environmental Impact Assessment Method & 37 & 1 & 0 & 1 & 0 \\
\hline 57 & Criminal Law & 452 & 21 & 4 & 23 & 2 \\
\hline 58 & Civil Procedure Law & 284 & 0 & 28 & 25 & 3 \\
\hline 59 & Criminal Procedure Law & 308 & 16 & 11 & 25 & 2 \\
\hline 60 & Administrative Procedure Law & 103 & 3 & 15 & 16 & 2 \\
\hline 61 & Arbitration Law & 80 & 0 & 4 & 3 & 1 \\
\hline 62 & International Criminal Judicial Assistance Law & 70 & 1 & 2 & 3 & 0 \\
\hline 63 & Total & 7087 & 438 & 149 & 542 & 45 \\
\hline
\end{tabular}

technology is not well developed, and the legislators are not used to danshu for the completeness and perfection of legal documents. Obviously, the small number of danshu is deeply influenced by the concept of "Legislation should be rough rather than fine" in specific historical period of China (Liu, 2016: pp. 346-348). At the beginning of the reform and opening up, many social relations are in the process of change. The legislative work at that time was of great exploratory characteristics, and it was difficult to take into account the details. This can be seen from the words Trial and Interim in the names of many laws and regulations at that time. After 40 years of reform and opening up, China's social relations have been basically stable, the legislative experience has become increa- 
singly rich. After the socialist legal system with Chinese characteristics has been formed, we can now carve out the law calmly (Liu, 2016: pp. 347-348), and dan$s h u$ is an important tool for the elaborating of legislative provisions.

\subsection{Exclusionary danshu Are Expressed by Syntactic Patterns of danshi, ... de chuwai (But ... Except), danshi, ... chuwai (But ... Except), and danshi, ... bu V (But ... Do Not) etc.}

There are 323 instances of exclusionary danshu, accounting for $60 \%$ of the total. Among them, 282 instances exclude the situations, 34 instances the objects, and 7 instances the subjects (see Table 3 below).This shows that the main function of danshu is to exclude the application of some legal rules to specific situation, $o b$ jects and subjects.

\subsubsection{When a situation Is Excluded, danshu Is Expressed by Syntactic} Pattern of danshi, ... de chuwai

This study finds 282 instances of danshu excluding situation, accounting for $87 \%$ of the total number of exclusionary danshu, $82 \%$ of which is expressed by syntactic pattern of danshi, ... de chuwai (see Table 3). For example:

(1) ... 但是, 其配偶再婚或者向婚姻登记机关书面声明不愿意恢复的除外。 (《民法典》第 51 条)

Table 3. Exclusionary danshu.

\begin{tabular}{|c|c|c|c|c|}
\hline Subclasses of exclusionary danshu & Syntactic patterns & Specific expressions & No. of instances & Per cent $(\%)$ \\
\hline \multirow{10}{*}{ Exclusion of the situations } & \multirow{3}{*}{ 1. danshi, ... de chuwai } & 1) danshi, ... de chuwai & 210 & $65.02 \%$ \\
\hline & & 2) danshi, ... chuwai & 52 & $16.10 \%$ \\
\hline & & 3) danshi, ... qinxing chuwai & 4 & $1.24 \%$ \\
\hline & \multirow{5}{*}{ 2. danshi, bu V... } & 1) danshi, ... bu renwei & 1 & $0.31 \%$ \\
\hline & & 2) danshi, ... buyu & 2 & $0.62 \%$ \\
\hline & & 3) danshi, ... bu cunzai & 1 & $0.31 \%$ \\
\hline & & 4) danshi, ... bu chansheng & 1 & $0.31 \%$ \\
\hline & & 5) danshi, ... meiyou & 1 & $0.31 \%$ \\
\hline & \multirow{2}{*}{ 3.Other patterns } & 1) danshi, yizhao... & 8 & $2.48 \%$ \\
\hline & & 2) danshi, ... cong qi guiding & 2 & $0.62 \%$ \\
\hline \multirow{7}{*}{ Exclusion of the objects } & \multirow{2}{*}{ 1. danshil dan, ... chuwai } & 1) danshi, ... chuwai & 13 & $4.02 \%$ \\
\hline & & 2) dan, ... chuwai & 10 & $3.10 \%$ \\
\hline & \multirow{5}{*}{ 2. danshi, bu V... } & 1) danshi, bu shiyong... & 2 & $0.62 \%$ \\
\hline & & 2) danshi, bu juyou... & 2 & $0.62 \%$ \\
\hline & & 3) danshi, bu jisuan... & 2 & $0.62 \%$ \\
\hline & & 4) danshi, ... bu shou yingxiang & 2 & $0.62 \%$ \\
\hline & & 5) danshi, ... wei bu dingqi... & 3 & $0.93 \%$ \\
\hline \multirow{2}{*}{ Exclusion of the subjects } & \multirow{2}{*}{ 1. danshil dan, ... chuwai } & 1) danshi, ... chuwai & 6 & $1.86 \%$ \\
\hline & & 2) dan, ... chuwai & 1 & $0.31 \%$ \\
\hline
\end{tabular}


... dàn shí, qí pèi ǒu zài hūn huò zhě xiàng hūn yīn dēng jị jị guān shū miàn shēng míng bú yuàn yì huĩ fù de chú wài.

... except where the spouse has married to someone else or states in writing to the marriage registration authority the unwillingness to resume the marriage. (Article 51 of Civil Code)

In (1), "qí pèi ó u ... de" is a de phrase, composed of an auxiliary de attached to a content word or phrase, which is a noun phrase, and can be used to designate people and objects, and thus can be used to function as the subject and the object grammatically (Huang \& Liao, 2011: pp. 50-51).

In legislative texts, the case element of legal norms is usually expressed by de phrase, and the legal sentences in Chinese laws can be generally expressed as (NP1) + VP1 + (NP2) + VP2 (Hu \& Jiang, 2016). The de phrase can refer to self-designation and transferred-designation (Zhu, 1983). There are two kinds of internal structure of $d e$ phrase. The first is " $[\mathrm{NP}+\mathrm{VP}]+d e$ ", and it regards the de phrase as a noun phrase (Zhou, 2002). The second is "NP + [VP + de]", in which "VP $+d e$ " is a post relative clause to modify the noun head (Dong, 2003). Most of the post relative clauses of $d e$ phrase can be converted into its prepositional form with the meaning basically unchanged. The de phrase has been an effective and unique expression tool by legal drafters in the past half century in China. It has completely replaced the word zhe (者) in the old legislative texts (Zhang, 2015).

As Danshu is a special legal norm (Zhou, 1991), so it also consists of three elements of assumption, treatment and sanction (Zhou, 1998: pp. 485-486). In the exclusionary danshu, the de phrase is usually used to exclude the application of certain legal rules in specific situations, such as:

（2）对于认罪认罚案件，人民法院依法作出判决时，一般应当采纳人民检 察院指控的罪名和量刑建议，但有下列情形的除外:

（一）被告人的行为不构成犯罪或者不应当追究其刑事责任的;

（二）被告人违背意愿认罪认罚的;

（三）被告人否认指控的犯罪事实的;

（四）起诉指控的罪名与审理认定的罪名不一致的;

(五) 其他可能影响公正审判的情形。(《刑事诉讼法》第 201 条)

duì yú rèn zuì rèn fá àn jiàn, rén mín fã yuàn yī fã zuò chū pàn jué shí, yī bān yīng dāng căi nà rén mín jiăn chá yuàn zhǐ kòng de zuì míng hé liàng xíng jiàn yì, dàn yǒu xià liè qíng xíng $d e$ chú wài:

The people's court shall generally adopt the charges and sentencing recommendations by the people's procuratorate when making judgment on a case to which the accused admits his guilt, with the exception of the following circumstances: (Article 201 of Criminal Procedure Law)

In (2), the danshu uses de phrase to exclude the five situations listed below the main clause, which makes the provisions more legible and orderly.

In legislative texts, sometimes NP in $d e$ phrase "NP + VP + de" can be omitted, that is, "VP $+d e$ " is used to refer to the person who carries out the act, which is transferred-designation in use. For example: 
（3）故意伤害他人身体的，处三年以下有期徒刑、拘役或者管制。(《刑法》 第 234 条)

gù yì shāng hài tā rén shēn tǐ de, chù sān nián yǐ xià yǒu qĩ tú xíng, jū yì huò zhě guăn zhì.

Whoever intentionally injures another person's body shall be sentenced to fixed-term imprisonment of not more than three years, criminal detention or public surveillance. (Article 234 of Criminal Law)

In (3), the de phrase refers to any person who has intentionally injured another person's body. The de phrase refers to the categorized people or things, behavior, nature, degree and the like, and most of them are associated with derogatory meanings. It has become a necessary language material for assumption element in legal norms (Sun, 2006: p. 90). In Criminal Law, almost all the assumption elements are expressed by de phrase.

It is found that the danshu for exclusion can also be expressed by syntactic pattern of danshi, ... de, yizhao... (but according to...). For example:

(4) ... 但是, 法律、法规另有规定的, 依照其规定(行政许可法, 第 43 条)

... dàn shì, fã lü, fã guī lìng yǒ u guĩ dìng de, yĩ zhào qí guĩ ding.

... but if otherwise provided by laws or administrative regulations, such provisions shall be followed. (Article 43 of Administrative License Law)

In addition, the danshu excluding the situations can also be expressed by syntactic pattern of danshi, bu V..., such as danshi, ... bu cunzai (but, ... does not exist), danshi, ... bu jiaona (but, does not pay...), danshi, ... bu chansheng (but, does not cause...). For example:

（5）... 但是，胎儿娩出时为死体的，其民事权利能力自始不存在。（《民法 典》第 16 条)

... dàn shî, tāi ér miăn chū shí wéi sǐ tǐ de, qí mín shi quán lì néng lì zì shǐ bú cún zài.

... However, a stillborn fetus does not have such capacity ab initio. (Article 16 of Civil Code)

\subsubsection{When Excluding the objects, danshu Can Be Expressed by Syntactic} Patterns of danshi, ... chuwai and danshi, bu V...

In this study, there are 38 danshu excluding the objects, among which 27 instances adopt danshi, ... chuwai (but except...). For example:

(6) 合伙人的债权人不得代位行使合伙人依照本章规定和合伙合同享有的 权利, 但是合伙人享有的利益分配请求权除外。(《民法典》第 975 条)

hé huǒ rén de zhài quán rén bú dé dài wèi xíng shǐ hé huǒ rén yī zhào běn zhāng guĩ dìng hé hé huǒ hé tóng xiăng yǒu de quán lì, dàn shì hé huǒ rén xiăng yǒu de lì yì fèn pèi quing qiú quán chú wài.

A creditor of a partner shall not subrogate and exercise any right of the partner provided in this Chapter and the partnership contract, except that a creditor may subrogate and exercise the partner's claim against the partnership for distribution of the benefits. (Article 975 of Civil Code)

In (6), the objects excluded in danshu is “the partner's claim against the partnership for distribution of the benefits". 
In addition, there are 11 danshu expressed by syntactic pattern of "danshi, bu V...”, such as:

（7）公证机构……五个工作日内向当事人出具公证书。但是, 因不可抗 力、补充证明材料或者需要核实有关情况的, 所需时间不计算在期限内。(《公 证法》第 30 条)

gōng zhèng jī gòu ... shí wǔ gè gōng zuò rì nèi xiàng dāng shì rén chū jù gōng zhèng shū. dàn shî, yīn bú kě kàng lì, bǔ chōng zhèng míng cái liào huò zhě xū yào hé shí yǒu guān qíng kuàng $d e$, suǒ xū shí jiān bú ji suàn zài qī xiàn nèi.

A notarial certificate shall be issued to the party concerned within 15 working days... However, in case of force majeure, providing supplementary materials or the need to verify the relevant circumstances, the time required shall not be included in the time limit. (Article 30 of Notarization Law)

In (7), the objects, namely "the time required in case of force majeure, for providing supplementary materials or the need to verify the relevant circumstances" are excluded.

\subsubsection{When Excluding the subjects, danshu Are Expressed by Syntactic Pattern of danshi, ... chuwai}

In this study, there are 7 danshu excluding the subjects, among which 6 are expressed by syntactic pattern of danshi, ... chuwai, and 1 of dan ... chuwai. For example:

（8）经人民法院通知, 证人没有正当理由不出庭作证的, 人民法院可以强 制其到庭, 但是被告人的配偶、父母、子女除外。(《刑事诉讼法》第 193 条 第 1 款)

jīng rén mín fã yuàn tōng zhī, zhèng rén méi yǒu zhèng dāng lĩ yóu bú chū tíng zuò zhèng de, rén mín fă yuàn kě yǐ qiáng zhì qí dào ting, dàn shì bèi gào rén de pèi ǒu、fù mǔv zǐ nŭ chú wài.

If, after being notified by the people's court, a witness fails to testify in court without justified reasons, the people's court may compel the witness to appear in court, with the exception of the spouse, parents and children of the defendant. (Paragraph 1 of Article 193, Criminal Procedure Law)

The danshu in (8) excludes the subjects, specifically the spouse, parents and children of the defendant.

In a word, de phrase is widely used in legislative provisions to indicate the assumption, to point out the preconditions, conditions or circumstances for the application of a certain legal rule, as well as in danshu to exclude certain situations, subjects and objects. When excluding the situations, danshu are mainly expressed by syntactic pattern of danshi, ... de chuwai, when excluding the subjects and the objects, danshu are mainly expressed by danshi, ... chuwai.

\subsection{The Authorization danshu Are Expressed by Syntactic Patterns of danshi, keyi ..., danshi, youquan ..., and danshi, bu chengdan...}

This study finds that 53 danshu granting positive freedom are mainly expressed 
by danshi, keyi ... (but, may...) and danshi, youquan ... (but, have the right to...), while 15 danshu granting negative freedom are expressed by danshi, bu chengdan ... (but, does not bear...). See Table 4 below.

\subsubsection{When It Comes to Positive Freedom, danshu Are Mainly Expressed} Syntactic Patterns of danshi, keyi ... and danshi ... de, keyi...

In this study, 53 danshu expressing positive freedom are found, among which 42 instances are expressed by danshi, keyi ..., including two specific forms of danshi, keyi ... and danshi ... de, keyi... For example:

（9）中介人未促成合同成立的，不得请求支付报酬；但是，可以按照约定 请求委托人支付从事中介活动支出的必要费用。(《民法典》第 946 条)

zhōng jiè rén wèi cù chéng hé tóng chéng lì de, bú dé qǐng qiú zhī fù bào chóu; dàn shi, kě y̌̀ àn zhào yuē dìng qĭng qiú wěi tuō rén zhī fù cóng shì zhōng jiè huó dòng zhī chū de bì yào fèi yòng.

Where a middleman fails to facilitate the conclusion of a contract, he may not request the payment of remuneration, but may request the client to pay for the necessary expenses incurred in the intermediary activities in accordance with the agreement. (Article 964 of Civil Code)

(10) 被告在作出行政行为时已经收集了证据，但因不可抗力等正当事由不 能提供的, 经人民法院准许，可以延期提供。(《行政诉讼法》第 36 条第 1 款)

bèi gào zài zuò chū xíng zhèng xíng wéi shí yǐ jīng shōu jí le zhèng jù, dàn yīn bú kě kàng lì děng zhèng dāng shì yóu bú néng tí gòng $d e$, jīng rén mín fă yuàn zhǔn xǔ, kě y̌ yán qī tí gong.

Table 4. Statistics of authorization danshu.

\begin{tabular}{|c|c|c|c|c|}
\hline $\begin{array}{l}\text { Subclasses of } \\
\text { authorization danshu }\end{array}$ & Syntactic patterns & Specific expressions & No. of instances & Percent (\%) \\
\hline \multirow{11}{*}{ Positive freedom } & \multirow{3}{*}{ 1. danshil dan, keyi... (but, may...) } & 1) danshi ... de, keyi... & 13 & $19.12 \%$ \\
\hline & & 2) dan ... de, keyi... & 10 & $14.71 \%$ \\
\hline & & 3) danshi..., keyi... & 19 & $27.94 \%$ \\
\hline & \multirow{4}{*}{ 2. danshil dan, youquan... (but, have the right to...) } & 1) danshi..., youquan... & 2 & $2.94 \%$ \\
\hline & & 2) danshi ... de, youquan... & 3 & $4.41 \%$ \\
\hline & & 3) danshi ... you ... quanli... & 1 & $1.47 \%$ \\
\hline & & 4) dan..., you xuanzequan... & 1 & $1.47 \%$ \\
\hline & \multirow{4}{*}{ 3. Other syntactic patterns } & 1) dan ... zhineng... & 1 & $1.47 \%$ \\
\hline & & 2) danshi ... de, ... huifu... & 1 & $1.47 \%$ \\
\hline & & 3) dan ... de, cong... & 1 & $1.47 \%$ \\
\hline & & 4) dan ... de, you... & 1 & $1.47 \%$ \\
\hline \multirow{5}{*}{ Negative freedom } & \multirow{2}{*}{ 1. danshi, bu chengdan... (but, does not bear...) } & 1) danshi ... de, bu chengdan... & 11 & $16.18 \%$ \\
\hline & & 2) danshi..., bu chengdan... & 1 & $1.47 \%$ \\
\hline & \multirow{3}{*}{ 2. Other danshi, bu $V$... (but, does not...) } & 1) danshi..., bu fang'ai... & 1 & $1.47 \%$ \\
\hline & & 2) danshi..., bu zai... & 1 & $1.47 \%$ \\
\hline & & 3) danshi..., bu хиуао... & 1 & $1.47 \%$ \\
\hline
\end{tabular}


If the defendant has collected evidence at the time of the administrative act, but cannot provide it due to force majeure and other legitimate reasons, the defendant may, with the permission of the people's court, postpone the provision of evidence. (Paragraph 1 of Article 36, Administrative Procedure Law)

The danshu in (9) and (10) are expressed by danshi, keyi ... and danshi ... de, keyi ... respectively. From the perspective of linguistic expression, the difference between the two forms lies in the use of de phrase, which can be attributable to the assumption element of legal rules. When danshu shares the same assumption element as that of its main clause, it usually takes the form of danshi, keyi..., as in example (9). When the assumption element in danshu differ from that of its main clause, it usually takes the form of danshi ... de, keyi..., where de phrase functions as assumption element, as in example (10).

There are 7 instances of danshu expressed by syntactic patterns of danshi, youquan..., and specifically including danshi, youquan..., danshi... de, youquan ... and dan... you xuanzequan etc. For example:

(11) 合伙事务由全体合伙人共同执行。按照合伙合同的约定或者全体合伙 人的决定, 可以委托一个或者数个合伙人执行合伙事务; 其他合伙人不再执 行合伙事务, 但是有权监督执行情况。(《民法典》第 970 条第 2 款)

hé huǒ shì wù yóu quán tǐ hé huǒ rén gòng tóng zhí xíng. àn zhào hé huǒ hé tóng de yuē dìng huò zhě quán tǐ hé huǒ rén de jué ding, kě yǐ wěi tuō yī gè huò zhě shù gè hé huǒ rén zhí háng hé huǒ shì wù; qí tā hé huǒ rén bú zài zhí xíng hé huǒ shì wù, dàn shì yǒu quán jiān dū zhí háng qíng kuàng.

The partnership businesses shall be jointly managed by all partners. One or more partners may be authorized to manage the partnership business in accordance with the partnership contract or the decision made by all partners; and the other partners shall cease to manage the partnership business, except that they have the right to supervise the management. (Paragraph 2 of Article 970, Civil Code)

In addition, there are 4 danshu indicating positive freedom are expressed in other syntactic patterns, such as danshi ... de, huifu..., and dan ... zhineng ..., etc.

\subsubsection{When Indicating Negative Freedom, danshu Are Mainly Expressed} in Negative Verb form Such as danshi, bu chengdan...

In this study, there are 15 danshu indicating negative freedom are found, among which 12 instances are expressed in syntactic pattern of danshi, bu chengdan... For example:

(12) 民用航空器造成他人损害的, 民用航空器的经营者应当承担侵权责任; 但是, 能够证明损害是因受害人故意造成的, 不承担责任。(《民法典》第 1238 条)

mín yòng háng kōng qì zào chéng tā rén sŭn hài de, mín yòng háng kōng qì de jīng yíng zhě yīng dāng chéng dān qīn quán zé rèn; dàn shi, néng gòu zhèng míng sǔn hài shì yīn shòu hài rén gù yì zào chéng $d e$, bú chéng dān zé rèn.

Where a civil aircraft causes damage to another person, the operator of the aircraft shall bear tort liability, provided that the operator shall not assume any 
liability if it can be proven that the damage is intentionally caused by the victim. (Article 1238 of Civil Code)

In addition, the sentence pattern danshi, bu $V$... can also be used to express danshu indicating negative freedom. For example:

（13）仅在下列情形下, 受害人可以直接对保险人或者担保人提起诉讼, 但 是不妨碍受害人根据有关保险合同或者担保合同的法律规定提起直接诉讼的 权利: (《民用航空法》第 168 条)

jǐn zài xià liè qíng xíng xià, shòu hài rén kě yǐ zhí jiē duì băo xiăn rén huò zhě dān băo rén tí qǐ sù song, dàn shi bú fáng ài shòu hài rén gēn jù yǒu guān băo xiăn hé tóng huò zhě dān băo hé tóng de fă lü guī dìng tí qĩ zhí jiē sù sòng de quán lì.

The victim may directly bring a lawsuit against the insurer or the guarantor only under the following circumstances, but it does not hinder the victim's right to bring a direct action in accordance with the relevant laws and regulations on the insurance contract or the security contract. (Article 168 of Civil Aviation Law)

Among the words used to grant rights and authorize power, the most frequent and stable words are keyi (may), youquan (have the right), and xiangyou (enjoy) etc., and among which the word keyi is most widely used (Liu, 2018: pp. 114-115).

\subsection{Obligatory shanshu Are Mainly Expressed by Syntactic Patterns of danshi, yingdang ... and danshi, bude..., and so on}

There are 81 danshu indicating positive obligations were expressed by danshi, yingdang..., and 79 danshu indicating negative obligations were expressed by danshi, bude..., see Table 5 below:

Table 5. Linguistic expressions of obligatory danshu.

\begin{tabular}{|c|c|c|c|c|}
\hline $\begin{array}{c}\text { Subclasses } \\
\text { of obligatory danshu }\end{array}$ & Syntactic patterns & Specific expressions & $\begin{array}{c}\text { No. of } \\
\text { instances }\end{array}$ & $\begin{array}{l}\text { Percent } \\
(\%)\end{array}$ \\
\hline \multirow{11}{*}{ Positive obligations } & \multirow{3}{*}{ 1. danshi, yingdang... } & 1) danshi, yingdang... & 44 & $27.5 \%$ \\
\hline & & 2) dan yingdang... & 13 & $8.13 \%$ \\
\hline & & 3) yingdang... & 3 & $1.88 \%$ \\
\hline & \multirow{3}{*}{ 2. danshi, bixu... } & 1) danshi, bixu... & 6 & $3.75 \%$ \\
\hline & & 2) dan bixu... & 3 & $1.88 \%$ \\
\hline & & 3) danshi bixu... & 2 & $1.25 \%$ \\
\hline & \multirow{5}{*}{$\begin{array}{l}\text { 3. Other syntactic } \\
\text { patterns }\end{array}$} & 1) danshi, ... you... & 6 & $3.75 \%$ \\
\hline & & 2) danshi, ... bu yingxiang... & 2 & $1.25 \%$ \\
\hline & & 3) danshi ... de, ... geiyu... & 1 & $0.63 \%$ \\
\hline & & 4) danshi ... de, ... yi... & 1 & $0.63 \%$ \\
\hline & & 5) danshi ... de, ... shiyong... & 1 & $0.63 \%$ \\
\hline \multirow{2}{*}{ Negative obligations } & \multirow{2}{*}{ 1. danshi, bude... } & 1) danshi, bude... & 40 & $25 \%$ \\
\hline & & 2) dan bude... & 21 & $13.13 \%$ \\
\hline
\end{tabular}




$\begin{array}{llll} & \text { 1) dan ... buyingxiang... } & 5 & 3.13 \% \\ & \text { 2) danshi, buneng... } & 3 & 1.88 \% \\ \text { 3) danshi, ... wuquan... } & 3 & 1.88 \% \\ \text { 2. danshi, bu } V . . . & \text { 4) danshi, ... bu chaoguo... } & 3 & 1.88 \% \\ & \text { 5) danshi, bu fang'ai... } & 3 & 1.88 \% \\ \text { 6) danshi..., ... de..., bu huifu... } & 1 & 0.63 \% \\ \text { 7) dan bu canjia... } & 1 & 0.63 \%\end{array}$

\subsubsection{When Expressing Positive Obligations, danshu Are Usually} Expressed by Syntactic Patterns of danshi, yingdang ... and danshi, bixu..., etc.

This study finds that danshu indicating positive obligations are expressed by danshi, yingdang... (60 instances) and danshi, bixu... (11 instances) and other syntactic patterns (10 instances) respectively. Among them, the pattern danshi, yingdang ... includes specific expressions of danshi, yingdang..., dan yingdang ... and yingdang..., etc. For example:

（14）基层人民法院和它派出的法庭审理简单的民事案件, 可以用简便方式 传唤当事人和证人、送达诉公文书、审理案件, 但应当保障当事人陈述意见 的权利。(《民事诉讼法》第 159 条)

jī céng rén mín fã yuàn hé tā pài chū de fã tíng shěn lĩ jiăn dān de mín shì àn jiàn, kě yĩ yòng jiăn biàn fāng shì chuán huàn dāng shì rén hé zhèng rén、 sòng dá sù sòng wén shū、shěn lĩ àn jiàn, dàn yīng dāng băo zhàng dāng shì rén chén shù yì jiàn de quán lì.

In trying simple civil instances, the basic people's courts and the courts dispatched by them may summon the parties and witnesses, serve litigation documents and try instances in a simple way, but the right of the parties to state their opinions shall be guaranteed. (Article 159 of Civil Procedure Law)

The syntactic pattern danshi, bixu... includes specific expressions of danshi, bixu..., dan..., bixu... and danshi xujing..., etc. For example:

(15) 文物保护单位的保护范围内不得进行其他建设工程或者爆破、钻探、 挖掘等作业。但是, ……的, 必须保证文物保护单位的安全, 并经核定公布 该文物保护单位的人民政府批准，在批准前应当征得上一级人民政府文物行 政部门同意; ……的，必须经省、自治区、直辖市人民政府批准，在批准前 应当征得国务院文物行政部门同意。(《文物保护法》第 17 条)

wén wù băo hù dān wèi de băo hù fàn wéi nèi bú dé jìn xíng qí tã jiàn shè gōng chéng huò zhě bào pòv zuàn tàn、wā jué děng zuò yè. $d a ̀ n ~ s h i, \ldots d e, b i$ xü băo zhèng wén wù băo hù dān wèi de ān quán, bìng jīng hé dìng gōng bù gāi wén wù băo hù dān wèi de rén mín zhèng fŭ pī zhǔn, zài pī zhǔn qián yīng dāng zhēng dé shàng yī jí rén mín zhèng fŭ wén wù xíng zhèng bù mén tóng yì; ... $d e, b i \mathbf{x} \bar{u}$ jīng shěng、zì zhì qū $、$ zhí xiá shì rén mín zhèng fǔ pī zhǔn, zài pĩ zhŭn qián yīng dāng zhēng dé guó wù yuàn wén wù háng zhèng bù mén tóng yì.

No other construction projects or blasting, drilling, excavation and other op- 
erations shall be carried out within the scope of protection of cultural relics protection units. But it is necessary to ensure the safety of the site to be protected for its historical and cultural value, and shall be approved by the people's government which has approved and published the site for protection of its cultural relics, and prior to approval, the consent of the administrative department for cultural relics of the people's government at the next higher level shall be obtained. The approval of the people's Government of a province, autonomous region or municipality directly under the central government must be obtained, and prior to approval, the consent of the administrative department for cultural relics under the State Council shall be obtained. (Article 17 of Law on the Protection of Cultural Relics)

The danshu in example (14) is expressed by danshi, yingdang ... and danshu in example (15) are expressed by 2 danshi, bixu...

In addition, the danshu indicating positive obligations can also be expressed by syntactic patterns such as danshi, ... you ..., danshi, ... bu yingxiang ..., danshi ... de, ... geiyu ..., etc. For example:

（16）董事会成员由国有资产监督管理机构委派；但是，董事会成员中的职 工代表由公司职工代表大会选举产生。(《公司法》第 67 条第 2 款)

dǒng shì huì chéng yuán yóu guó yǒu zī chăn jiān dū guăn lǐ jī gòu wěi pài; dàn shi, dǒng shì huì chéng yuán zhōng de zhí gōng dài biăo yóu gōng sī zhí gōng dài biăo dà huì xuăn jŭ chăn shēng.

The members of the board of directors shall be appointed by the state-owned assets supervision and administration institution; however, the employee representatives among the members of the board of directors shall be elected by the staff congress of the company. (Paragraph 2 of Article 67, Company Law)

The danshu indicating positive obligations are often expressed by the terms yingdang (shall), yinggai (shall), bixu (must), etc. (Zhang, 2018: p. 118; Xu \& Bian, 2017: p. 303). However, there are some differences in the degree between the term yingdang and bixu, so the latter must be used in some circumstances (Liu, 2007: pp. 119-120). This study finds that danshu indicating positive obligation are mainly expressed by syntactic patterns of danshi, yingdang... and fewer instances by danshi, bixu ... and danshi, yizhao..., etc. The term yingdang in ethics refers to the provisions required by morality (Editorial Board, 2010: p. 2280). Law is the minimum moral standard, therefore, the term yingdang is widely used in legislative texts, which shows that the obligor shall perform certain positive obligations to ensure the realization of other people's rights.

\subsubsection{When Indicating Negative Obligations, danshu Are Expressed by Syntactic Patterns of danshi, bude... and danshi, bu V...}

This study finds that 61 danshu indicating negative obligations are expressed by danshi, bude..., and specifically by danshi, bude ... (40 instances) and dan ... bude ... (21 instances) respectively. For example:

（17）法律对行政处罚及处罚机关有其他规定的，从其规定。但是，对同一 违法行为不得重复处罚。(《农产品质量安全法》第 52 条第 2 款) 
fã lù duì xíng zhèng chù fá jí chù fá jī guān yǒu qí tā guī dìng de, cóng qí guī ding. dàn shì, duì tóng yī wéi fã xíng wéi bú dé zhòng fù chù fá.

If the law has other provisions on administrative penalty and penalty organs, such provisions shall prevail. However, the same illegal act shall not be punished repeatedly. (Paragraph 2 of Article 52, The Law on the Quality and Safety of Agricultural Products)

This study also finds 18 danshu indicating negative obligations are expressed by syntactic pattern of danshi, bu V..., including specifically danshi, ... wuquan..., danshi, ... bu chaoguo ... and danshi, bu fang ai... For example:

(18)房地产抵押合同签订后, 土地上新增的房屋不属于抵押财产。需要拍卖 该抵押的房地产时, 可以依法将土地上新增的房屋与抵押财产一同拍卖, 但 对拍卖新增房屋所得, 抵押权人无权优先受偿。(《城市房地产管理法》第 52 条)

fáng dì chăn dĩ yā hé tóng qiān dìng hòu, tǔ dì shàng xīn zēng de fáng wū bú shǔ yú dǐ yā cái chăn. xū yào pāi mài gāi dĩ yā de fáng dì chăn shí, kě yǐ yī fã jiāng tǔ dì shàng xīn zēng de fáng wū yǔ dǐ yā cái chăn yī tóng pāi mài, dàn duì pāi mài xīn zēng fáng wū suǒ dé, dǐ yā quán rén wú quán yōu xiān shòu cháng.

When it is necessary to auction the mortgaged real estate, the newly added houses on the land may be auctioned together with the mortgaged property in accordance with the law, but the mortgagee has no priority to be compensated for the income from the auction of the new houses. (Article 52 of Law of Urban Real Estate Management)

When people are asked not to carry out certain behavior, the negative obligations are usually expressed by core terms of bude ... (may not) and jinzhi ... (prohibit) etc. (Xu \& Bian, 2017: p. 304). Zhang Wenxian (2018: p. 118) also points out that the terms bude, jinzhi and yanjin (prohibit) etc. are employed to express negative obligations, or the adverse legal consequences are added after describing the behavior mode. This study finds that danshu indicating negative obligations are most widely expressed by syntactic pattern of danshil dan, bude...

In a word, among the terms in legislative texts, some core terms are necessary to play the dominant role. Core terms are the most widely used linguistic materials for the expression of legal norm, which support the framework of legislative texts (Liu, 2018: p. 114). According to Gong Mingyu et al. (2020: pp. 348-349), it takes a fairly long time for the deontic terms keyi, yingdang and bude to establish a dominant share in the expression of rights and obligations respectively, and they takes this dominant place in 1990, 1991 and 1990 respectively. No matter what the specific form is, the core terms can be used to express the same meaning, but the form should be adjusted according to the content and context of legislative texts (Liu, 2018: pp. 115-116).

\subsection{The Disyllabic Tendency of the Introductory Words of danshu}

First, the use and function of the words dan and danshi are basically the same. In modern Chinese, the words dan and danshi are basically the same in use ... (Zhang, 2001: p. 131). In modern legislative texts, both dan and danshi can be 
used to introduce danshu, and their roles and functions are the same (Legislative Affairs Committee of NPC, 2009). Yao Shuangyun (2017: p. 218) finds that in legal provisions, danshi appears 136 times, with 47.5 times of standardization per 100,000 words; 123 times of dan and 43.0 times of standardization per 100,000 words.

Second, there is a disyllabic tendency of the introductory words in danshu. This study finds that 422 instances of danshu are introduced by danshi and only 120 instances by dan. Before the promulgation of the Civil Code, the danshu in the General Provisions of Civil Law, Contract Law, Property Law and other civil laws are introduced by dan and danshi interchangerably in most instances. As stated by Zhou Wangsheng (2009: p. 482), in legislative texts, the same words and concepts should express the same meaning, and different words and concepts should express different meanings. For example, danshu in the same law or code cannot be introduced by dan and danshi interchangeably (Zhou, 2009: p. 482). Finally, 215 danshu of Civil Code are exclusively introduced by disyllabic danshi, which shows that the codification of laws can not only promote the scientification but also the normalization of legislation, and there is a disyllabic tendency of the introductory words in danshu in Chinese legislation. The codification of Civil Code provides rich experience in the normalization of linguistic expression of legislative texts.

\section{Conclusion}

This study has described the linguistic expressions of danshu (provisos) in Chinese laws, and it will shed light on the standardization of Chinese laws, especially the syntactic patterns and core lexis of danshu thereof. Based on a self-built mini-corpus of danshu of Chinese legislative texts, this study has classified danshu into four types according to their content, and finds that: 1) the linguistic expressions of exclusionary danshu. When excluding the situations, danshu are expressed by syntactic pattern of danshi, ... de chuwai (but ... except); when excluding the objects and the subjects, danshu are expressed by danshi, ... chuwai (but ... except). 2) The linguistic expressions of authorization danshu. When indicating positive freedom, danshu are mainly expressed by syntactic pattern of danshi, keyi ... (but ... may), while those for negative freedom by danshi, bu chengdan ... (but ... does not bear...). 3) The linguistic expressions of obligatory danshu. The danshu imposing positive obligations are mainly expressed by syntactic pattern of danshi, yingdang ... (but ... shall), and those imposing negative obligations by danshi, bude ... (but ... shall not). 4) There is a disyllabic tendency for the introductory words of danshu, namely a shift from dan (but) to danshi (but/however). This study describes quantitatively the linguistic expressions of danshu, and discusses the syntactic pattern and core lexis of each sub-types based on its content, and the research result will be more objective and reliable.

According to the variability of language, the proviso in each language has its features, and this study has just discussed the linguistic expression of danshu 
(proviso) in Chinese legislative texts, and further work could include the linguistic expressions of provisos in other languages.

\section{Supported}

This study is supported by Shanghai Planning Office of Philosophy and Social Science (立法条文中“条件”的语言表述研究, 项目编号 2019BYY010).

\section{Conflicts of Interest}

The authors declare no conflicts of interest regarding the publication of this paper.

\section{References}

Biber, D., \& Conrad, S. (2009). Register, Genre, and Style (pp. 4-5). New York: Cambridge University Press. https://doi.org/10.1017/CBO9780511814358

Crystal, D., \& Davy, D. (1969). Investigating English Style. London and New York, NY: Routledge.

Dong, X. F. (2003). The Use of de Phrase as a Post Relative Clause: Comments on the Use of de Phrase in Legislative Texts. Applied Linguistics, 4, 120-126.

Doonan, E., \& Foster, C. (2001). Drafting (2nd ed.). London/Sydney: Cavendish Publishing Limited. https://doi.org/10.4324/9781843140986

Editorial Board (2010). Encyclopedia of Chinese Characters [cí hăi] (6th ed.). Shanghai: Shanghai Cishu Publishing House.

Garner, A. B. (2019). Black's Law Dictionary(11th ed.). St. Paul, MN: Thomson Reuters.

Gong, M. Y., Cheng, W., \& Cheng, L. (2020). Development of Deontic Modality in Chinese Civil Laws: A Corpus Study. Pragmatics and Society, 11, 337-362.

https://doi.org/10.1075/ps.16058.gon

Hu, D. H., \& Jiang, C. G. (2016). Translation of De Constructions from Legal Sentences under the Guidance of Self-Designation and Transferred-Designation. Language and Translation, 3, 45-52.

Huang, B. R., \& Liao, X. D. (2011). Modern Chinese [xiàn dài hàn yǔ] (5th ed., Part II). Beijing: Higher Education Press.

Legislative Affairs Committee of the National People's Congress (2009). Technical Guideline for Legislation (Trial, Part I) [lì fã jì shù guī fàn (shì xíng)]. Document Code: [2009]62.

Liu, H. Y. (2007). Legal Linguistics [fă lù̀ yǔ yán xué] (2nd ed.). Beijing: Peking University Press.

Liu, H. Y. (2018). Legal Linguistics [fă lǜ yǔ yán xué]. Beijing: Higher Education Press.

Liu, S. S. (2016). Research on Chinese Legislation [zhōng guó lì fă wèn tí yán jiū]. Beijing: Intellectual Property Publishing House.

Luo, H. Y., \& Wang, S. (2018). The Transitional Sentences in Legislative Language in the Cases of the dan and danshi Sentences. Contemporary Rhetoric, 6, 77-89.

Mellinkoff, D. (2014). The Language of the Law. Translated by Liao Meizhen. Beijing: Law Press China.

Pan, Q. Y. (2004). Law Language Is a Technical One Different from National Language. Journal of Jianghan University (Humanities Sciences), 2, 18-22. 
Pan, Q. Y. (2017). Legal Linguistics [fă lǜ yǔ yán xué]. Beijing: China University of Political Science and Law Press.

Sun, Y. H. (2006). Legal Linguistics [fă lù yǔ yán xué]. Changsha: Hunan People’s Publishing House.

Tammelo, I. (2012). Modern Logic in the Service of Law. Beijing: China Legal Publishing House.

Xu, X. H., \& Bian, L. (2017). A Coursebook for Legislation [lì fă xué jiāo chéng] (2nd ed.). Beijing: Peking University Press.

Yao, S. Y. (2017). Discourse-Type Based Studies on Chinese Conjunction [guān lián biāo jì de yǔ tǐ chà yì xìng yán jiū]. Beijing: World Publishing Corporation.

Yu, M. X., \& Wang, Z. H. (2017). A Discourse Semantic Approach to Qita (Other) in the Criminal Law of China [wǒ guó fă lù̀ yǔ yán zhōng "qí tā "yī cí de yǔ piān yǔ yì fèn xī]. Contemporary Rhetoric, 6, 23-32.

Zhang, B. (2001). The Dictionary of Modern Chinese Function Words [xiàn dài hàn yǔ xū cí cí diăn]. Beijing: The Commercial Press.

Zhang, B. J. (2015). The Language of Laws and Regulations Should be Normalized Chinese [fă lù fă guī yǔ yán yīng chéng wéi yǔ yán guī fàn de shì fàn]. Contemporary Rhetoric, 5, 1-7.

Zhang, W. X. (2018). Jurisprudence [fă lǐ xué] (5th ed.). Beijing: Higher Education Press.

Zhou, W. S. (1991). On Danshu (Proviso) in Legislative Texts [lùn fă lù dàn shū]. China Legal Science, 4, 54-62.

Zhou, W. S. (1998). On the Drafting of Legal Doduments [gui fàn xìng wén jiàn qĩ căo]. Beijing: National People's Congress Publishing House.

Zhou, W. S. (2009). Legislation [lì fă xué] (2nd ed.). Beijing: Law Press China.

Zhou, X. L. (2002). An Analysis of Ungrammatical or Ill-Formed Sentences in the Texts of Administrative Laws and Suggestions for Revision [xing zhèng fă lü yŭ bìng lì xī]. Applied Linguistics, 3, 64-67.

Zhu, D. X. (1983). Self-Designation and Transferred-Designation [zì zhǐ hé zhuăn zhǐ]. Dialect, 1, 16-31.

Zhu, L. Y., \& Ye, C. X. (2015). Legislation [lì fă xué] (4th ed.). Beijing: China Renmin University Press. 